\title{
The Seasonal Variability and Sedimentation Rate of Suspended Matter in Photic Layer of the Black Sea
}

\author{
E.Z. Samyshev", N.I. Minkina \\ Department of Marine Ecosystems Functioning, A.O. Kovalevsky Institute of Marine Biological Researches, \\ Russian Academy of Science, Russian Federation
}

Copyright $(2017$ by authors, all rights reserved. Authors agree that this article remains permanently open access under the terms of the Creative Commons Attribution License 4.0 International License

\begin{abstract}
Monitoring of the annual cycle of main components of ecosystem of the Black Sea was carried out in the economic area of the ex-USSR during 1992 - 1993. As a part of the programme, suspended matter content, organic fractions and sedimentation rates in photic zone of the sea were investigated with the involvement of research vessels of the Ukrainian Research Centre of Ecology of Sea (UkrRCME). The investigation has shown that at known prevailing of particulate organic matter over abundance of structural elements of seston, seasonal changes in its content in the open sea agreed with seasonal changes in the abundance of plankton organisms; sedimentation rate of organic particles in photic zone was high and is driven by the hydrodynamic activity.
\end{abstract}

Keywords Black Sea, Suspended Organic Matter, Plankton, Productivity, Functional Role, Sedimentation Rate

\section{Introduction}

Scientific evidence about total suspended matter (TSM), its organic fraction (suspended organic matter, SOM) and their sedimentation rates can be of use in assessment of productivity and understanding of bioproduction generation and sedimentation processes in diverse water bodies [2,17, $20]$.

Considering this aspect, coastal zones of the Black Sea were carefully and repeatedly studied. Most of the investigations were related to geology and assessed horizontal (from the shore towards the sea) and vertical fluxes of sedimentation material [14].

In recent decades, insight into suspended organic matter (SOM) of the Black Sea was formed due to some regional [25-28] and regular investigations launched by Institute of Biology of the Southern Seas (IBSS) and Marine Hydrophysical Institute (MHI) [4]. These works have clarified the distribution and composition of SOM on the shelf and in an active layer of the deep-water zone of the Black Sea in different seasons of a year.

Little is known about SOM sedimentation in the deep-water zone of the sea. No doubt, direct measurements of sinking particulate matter using sediment traps $[1,11,12$, $16,24]$ provide valuable information thereby permitting one to assess sedimentation extent; however, this technique is of little use if the researcher wants to gain insight into the early stage of sedimentation carryover of non-transformed particulate matter going in active layer of the open sea and to compare this removal and the abundance of seston in photic zone. Interestingly, some researchers [10] used ${ }^{234} \mathrm{Th}$ as a tracer when detecting the transfer of particulate substances from the surface layer of the Black Sea during regular surveys made in the western cyclonic gyre in different seasons of $1992-1993$. This experience is of special interest with regard to methodology, too: exactly at that time we measured SOM content and sedimentation rate by means of sediment traps (ST) positioned in different locations of the sea and in different seasons. These measurements which were within the framework of regular multidisciplinary investigations of ecosystem of the Black Sea initiated by the Ukrainian Research Centre of Marine Ecology (UkrRCME), Odessa $[13,15]$ allow comparing the data on SOM having been obtained by different methods (see below).

\section{Materials and Methods}

According to Agreement about Scientific Cooperation between IBSS and MHI that involved investigations of annual cycle of main elements of ecosystem of the northern Black Sea, material for our investigation was collected during expeditions on the RVs of the URCME during $1992-$ 1993. Scientific scenario of the experiment was worked out and implemented under the supervision of V.I. Medinets. Phyto-, nano-, meso-, zoo- and bacterioplankton, TSM and SOM and their sedimentation rates in photic layer were studied by the scientific team headed by E.Z. Samyshev (IMBR, former A.O. Kovalevsky Institute if Biology of the 
Southern Seas (IBSS)) during six large-scale multidisciplinary expeditions conducted in conformity with the uniform scenario and map of sampling stations (Fig. 1). Samples of TSM and SOM and other seston components were collected during five complex surveys made in May, July, September and November-December 1992 and in February 1993. Samples of the particulate matter were taken during the surveys from depths in which light corresponded to $100,50,25,10$ and $1 \%$ of solar irradiance on the sea surface and from three daily stations located in the northwestern, central and eastern parts (st. 23, 55 and 96, correspondingly) of the Black Sea.

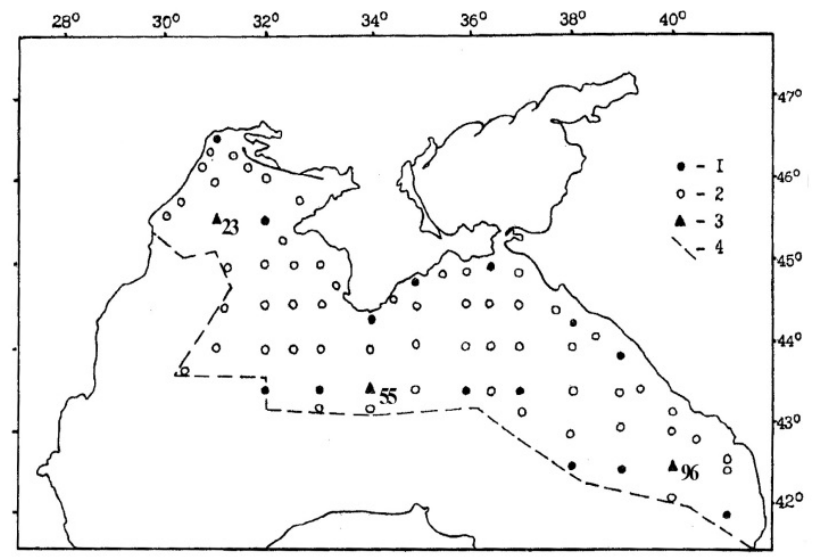

1 - full-scale observations; 2 - selective observations; 3 - daily stations; 4 the economic zone boundary.

Figure 1. The map of sampling stations under the ecological monitoring of the Black Sea from the RVs of UkrRCME.

For studying the particulate substances and phyto-, bacterio- and nanoheterotrophic plankton in seston, seawater samples were synchronously taken from a 30-1 plastic water sampler. Samples of deposited particulate matter were collected at daily stations by means of a floating stretching vertical set of three detritus traps [5]. The device was adjusted so that the upper and the middle traps were above and below thermocline, correspondingly; and the lower was at the depth of $65 \mathrm{~m}$ (st. 55 and 96) and $40 \mathrm{~m}$ (st. 23). Exposition time varied from 12 to 23 hours. The samples were preliminary handled and the suspended matter filtered onto preliminary weighed ashless membrane filters $(0.45 \mu \mathrm{m}$ pore size) using routine procedure. SOM content was determined by combustion on the filter at $450^{\circ} \mathrm{C}$. The portion of SOM in TSM was derived from the difference between TSM and ash fraction. Weighted averages of tested seston components were calculated using planimeter.

\section{Results and Discussion}

Being aware of current terminological discrepancies, we should explain that, in our interpretation, suspended organic matter (SOM) is the organic fraction incorporated into total suspended matter (TSM). The latter, in our case, is the net fraction of seston which remained after separation of the large-size fraction using sieve № $68(76 \mu \mathrm{m})$. Therefore, SOM is organic detritus (trypton), and phyto-, bacterio-, nano- and microzooplankton. In sea water, organic detritus usually contributes $80-99 \%$ to SOM [21-23]. In the Black Sea, however, "suspended particles are mainly pelite (from 70 to $90 \%$ )" and "as depth increases from 8 to $15 \mathrm{~m}$, content of suspended matter decrease. From $30-35 \mathrm{~m}$ depth and deeper, sedimentation acquires pelagic character" [14]. The trace amounts found in the open sea are, probably, due to spatial dispersion of terrigene sediments, and seasonal cycles going in pelagic biocenosis develop against this background. Figures 2,3,4,6 and Table show that seasonal content of SOM agrees with seasonal succession of all components of living plankton. In photic layer for the period from May to November 1992, synchronously with the declined abundance of phyto-, bacterio- and nanoheterotrophic plankton, SOM has decreased three-fold from the initial estimate of $2.03 \mathrm{mg}$ dry weight $\cdot 1^{-1}$, and in February 1993 - four-fold. During the first half of 1992, the estimates of SOM and other microplankton have been high until September: for instance, the average derived for phytoplankton in March - April was $2900 \mathrm{mg} \cdot 1^{-1}$. The depression that has stricken the biocenosis after was due to circulation transformation related to atmospheric processes. Concurrently, the observations have detected drastic spatial heterogeneity and variability of oceanographic parameters [6, 13] (Fig. 5) and biological characteristics practically all over the Black Sea. At the same time, in most cases SOM values ranged from 40 to $60 \%$ of TSM, whereas the acknowledged limits are from 20 to $92 \%$ (Fig. 4).

In comparison with estimates derived for the integral Global Ocean and individually for the Pacific Ocean $[17,19]$, our data suggest that in the Black Sea the content of SOM is an order of magnitude greater. Moreover, these estimates evidence nearly a three-fold increase of eutrophication since the 1960s [7]. 

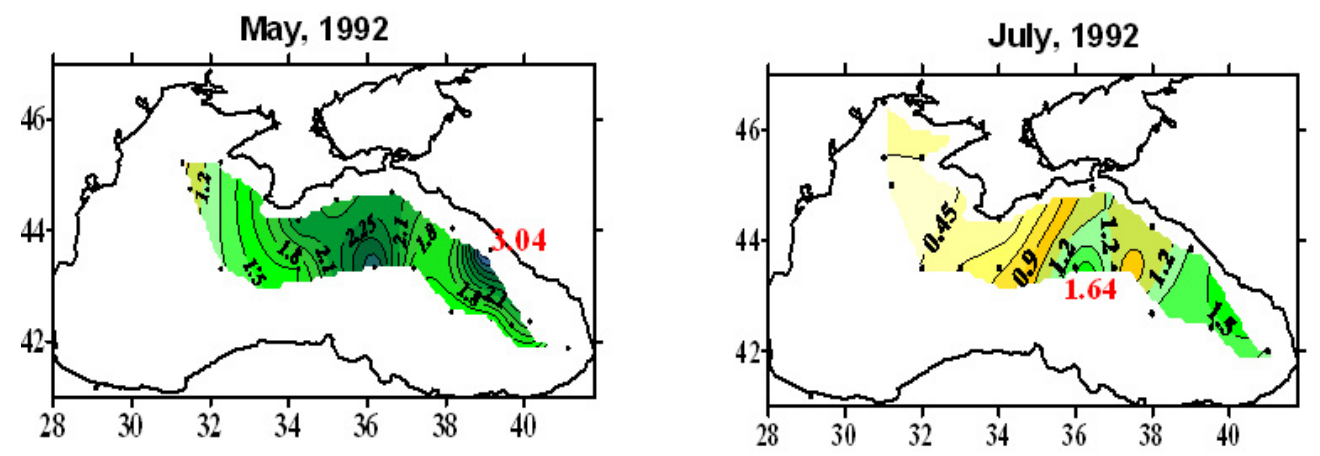

September, 1992
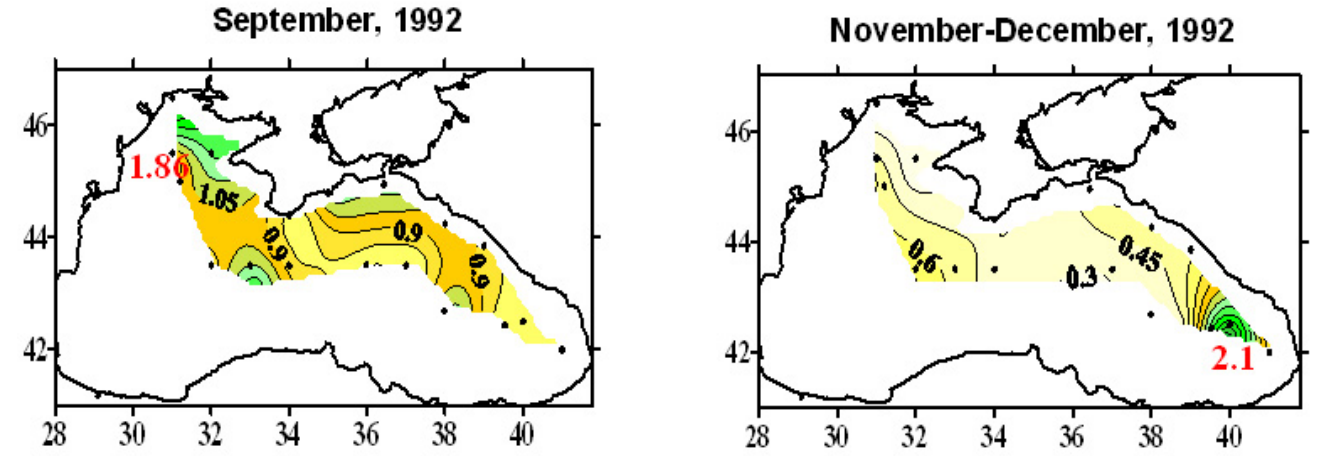

February, 1993

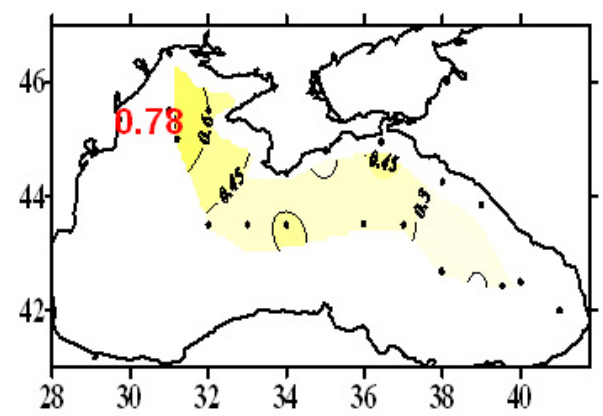

Figure 2. The spatial distribution of suspended organic matter (SOM) (mg dry weight $\left.\cdot 1^{-1}\right)$ in photic layer of the Black Sea in different seasons, $1992-1993$ 


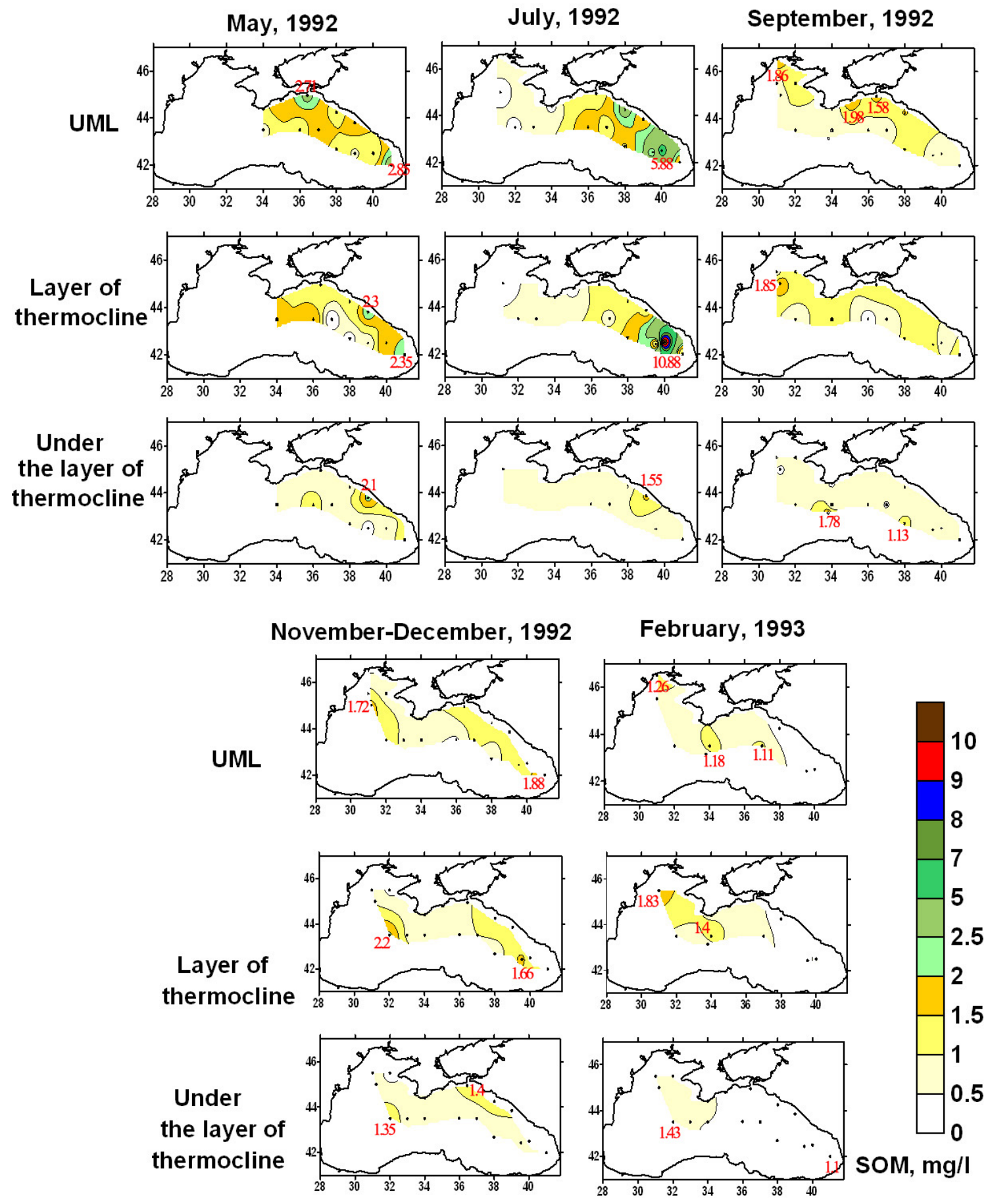

UML: upper mixed layer

Figure 3. The content of suspended organic matter $(\mathrm{SOM})\left(\mathrm{mg}\right.$ dry weight $\left.\cdot 1^{-1}\right)$ measured in the main pelagic layers of the Black Sea 
UML

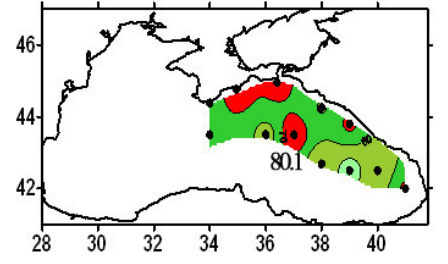
July, 1992

September, 1992
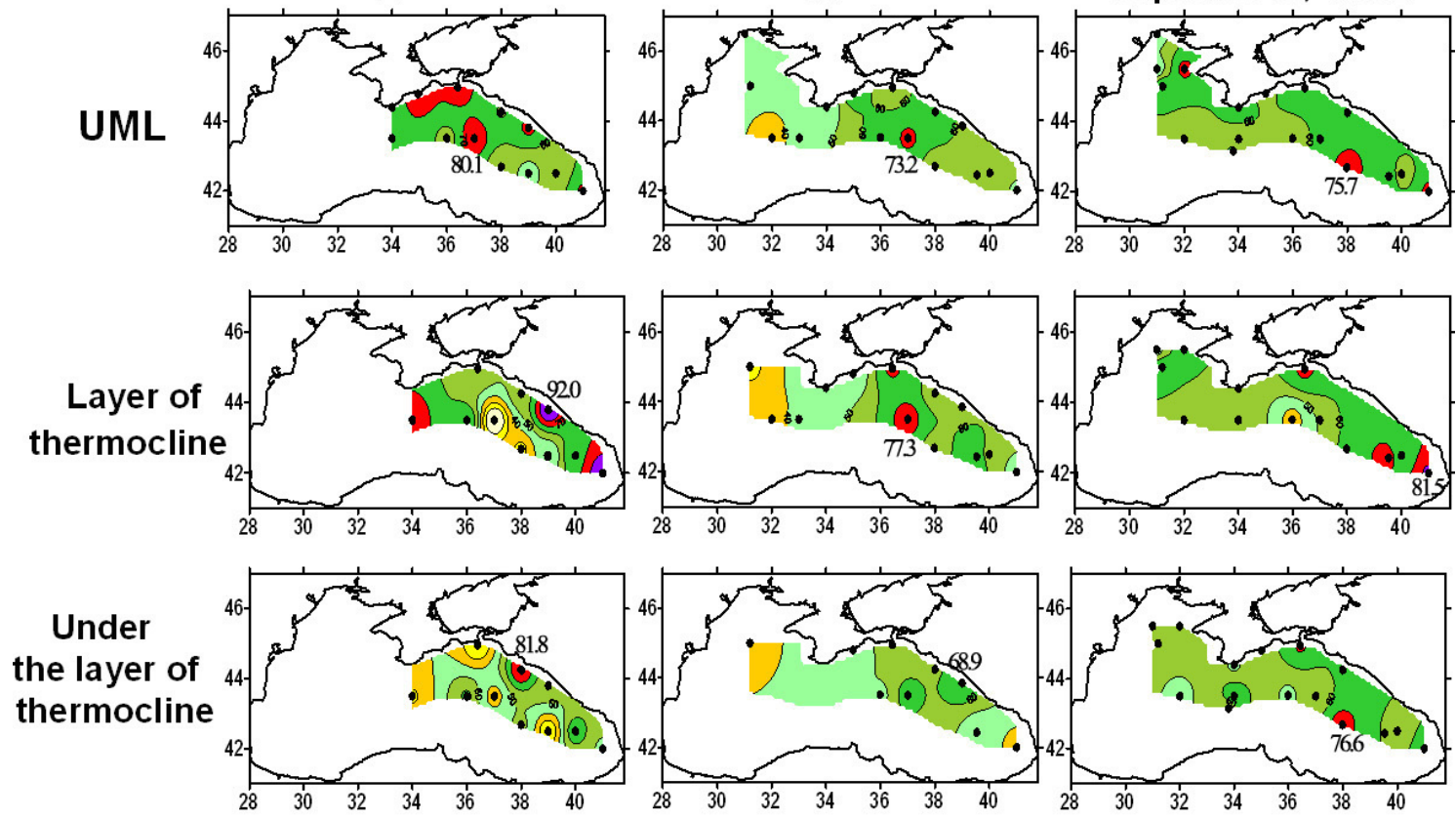

November-December, 1992 February, 1993

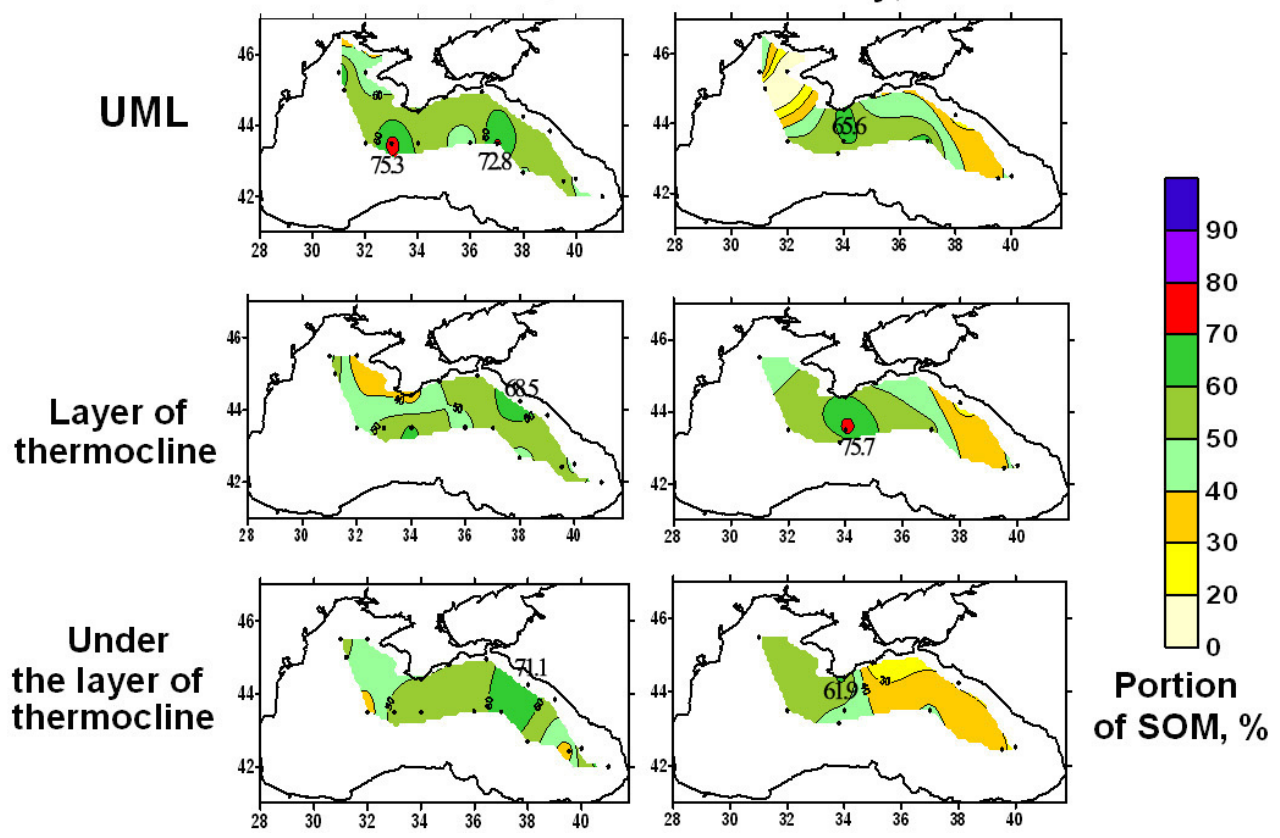

Figure 4. The portion of SOM in total suspended matter (TSM) (\%) measured in the main pelagic layers of the Black Sea 

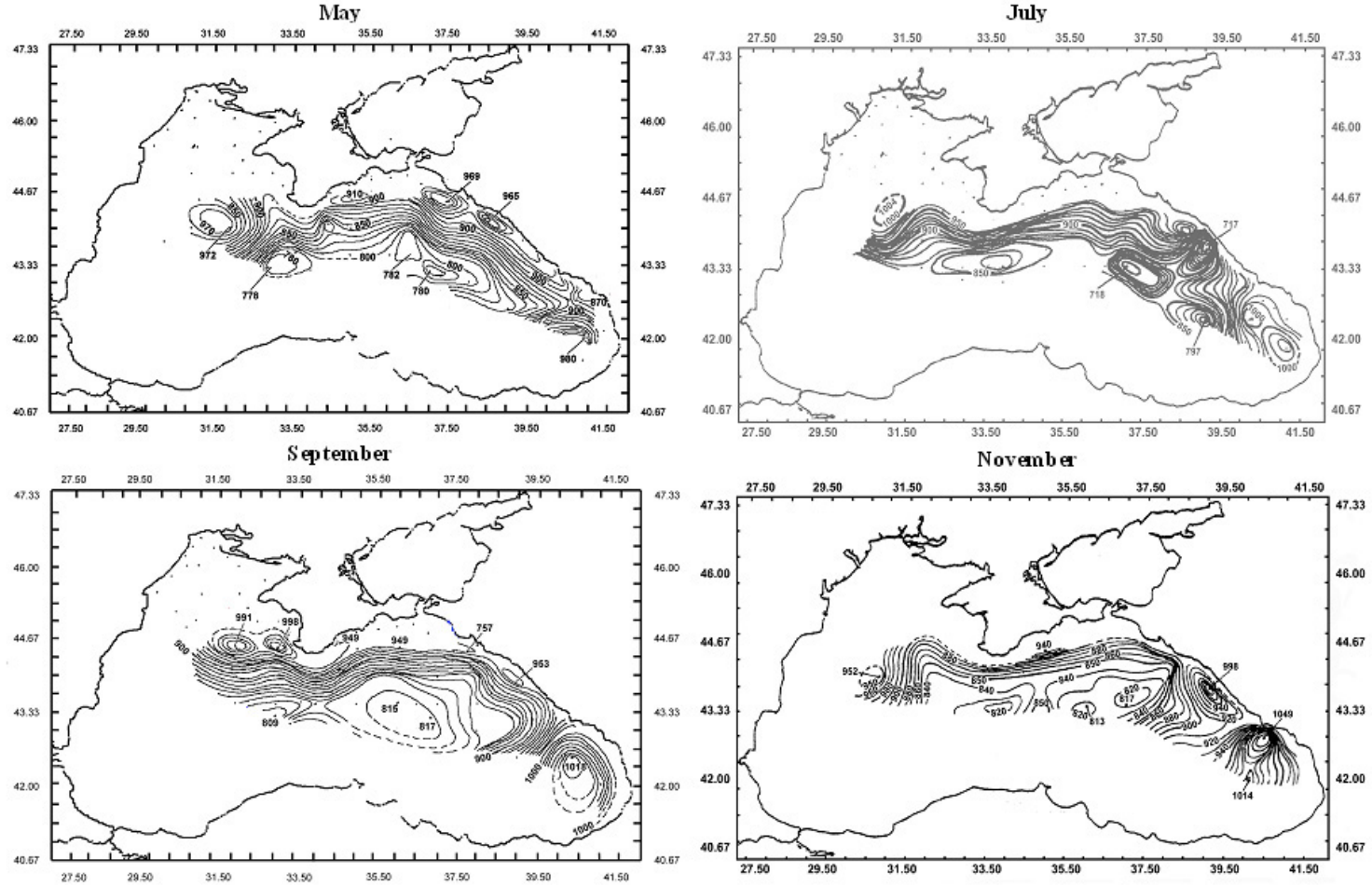

Figure 5. The dynamic topography of horizon $0 \mathrm{~m}$ from the spring to the autumn, 1992 by [8]

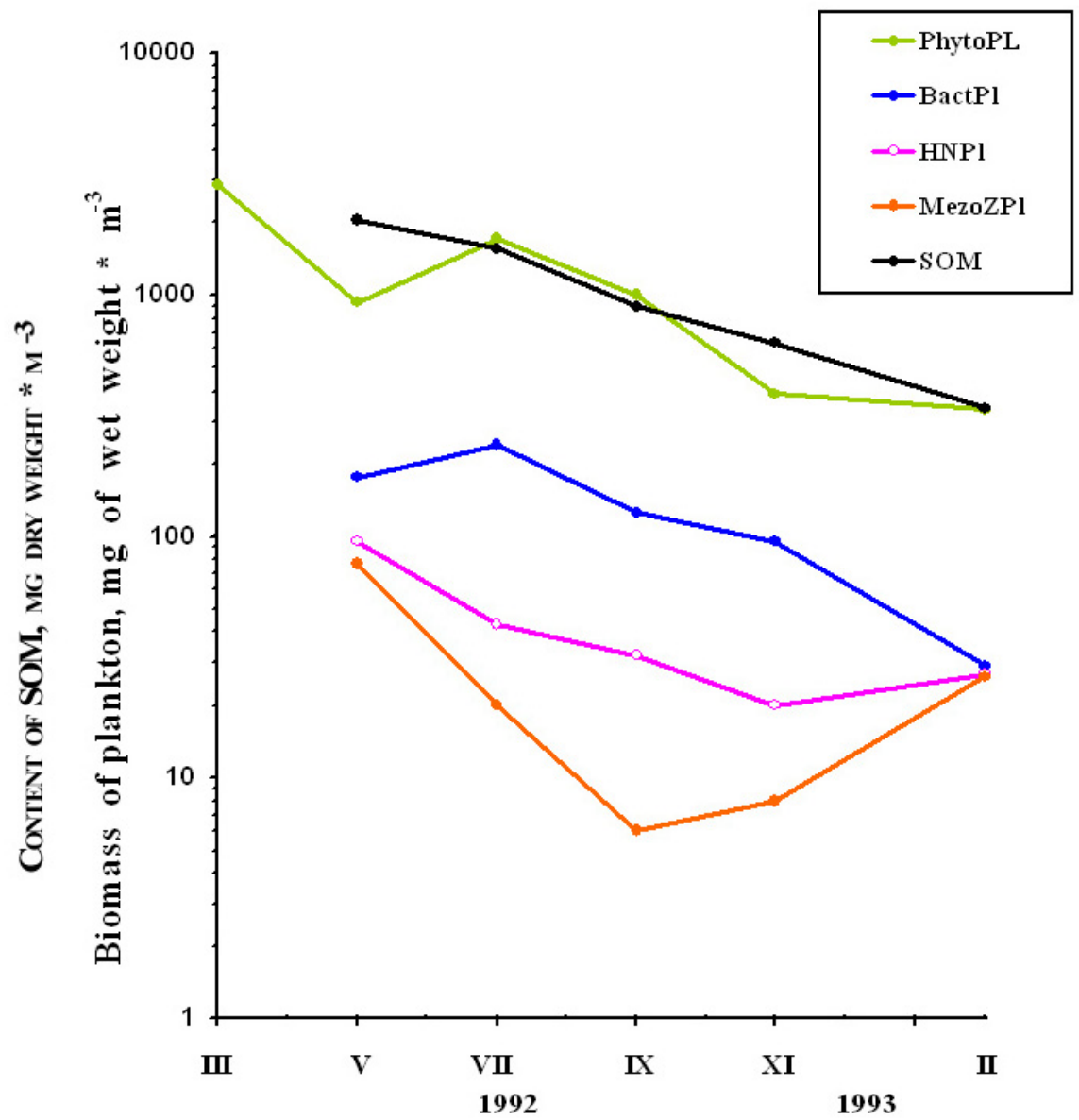

PhytoPl - phytoplankton (by [3]), BactPl - bacterioplankton (by [18]), MesoZPl - mesozooplankton (by [9]), HNPl - heterothrophic nanoplankton (by [18])

Figure 6. The seasonal changes of suspended organic matter (SOM) content and the biomass of plankton in photic layer of the Black Sea 
Table 1. Sedimentation rates of TSM and SOM $\left(\mathrm{g} \cdot \mathrm{m}^{-2} \cdot\right.$ day $\left.^{-1}\right)$ in the Black Sea

\begin{tabular}{|c|c|c|c|c|c|c|c|c|c|}
\hline \multirow{3}{*}{$\begin{array}{l}\text { Station №№ and } \\
\text { coordinates }\end{array}$} & \multicolumn{3}{|c|}{ May } & \multicolumn{3}{|c|}{ July } & \multicolumn{3}{|c|}{ September } \\
\hline & \multirow{2}{*}{$\begin{array}{c}\text { Depth of } \\
\text { measurement } \mathrm{H}, \mathrm{m}\end{array}$} & \multicolumn{2}{|c|}{$\begin{array}{l}\text { Sedimentation rate, } \\
\mathrm{g} \mathrm{m}^{-2} \text { day }^{-1}\end{array}$} & \multirow{2}{*}{$\mathrm{H}, \mathrm{m}$} & \multicolumn{2}{|c|}{ 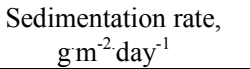 } & \multirow[t]{2}{*}{$\mathrm{H}, \mathrm{m}$} & \multicolumn{2}{|c|}{ 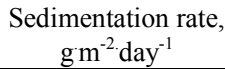 } \\
\hline & & TSM & SOM & & TSM & SOM & & TSM & SOM \\
\hline 23 & 18 & 1.28 & 0.80 & 12 & 1.13 & 0.79 & 18 & 1.20 & 0.60 \\
\hline $45.5^{\circ} \mathrm{N}$ & 26 & 0.83 & 0.49 & 25 & 0.24 & 0.16 & 30 & 0.67 & 0.31 \\
\hline $31^{\circ} \mathrm{W}$ & 38 & 1.20 & 0.49 & - & - & - & 40 & 0.36 & 0.22 \\
\hline 55 & 11 & 0.96 & 0.76 & 12 & 4.57 & 2.40 & 19 & 0.18 & 0.11 \\
\hline $43.5^{\circ} \mathrm{N}$ & 24 & 1.03 & 0.45 & 25 & 4.21 & 2.71 & 26 & 0.25 & 0.17 \\
\hline $34^{\circ} \mathrm{W}$ & 64 & 0.51 & 0.40 & 65 & 2.18 & 1.00 & 65 & 0.27 & 0.12 \\
\hline 96 & 6 & 1.57 & 1.05 & 8 & 1.20 & 0.66 & 19 & 0.33 & 0.19 \\
\hline $42.5^{\circ} \mathrm{N}$ & 25 & 1.15 & 0.74 & 26 & 1.79 & 1.19 & 35 & 1.02 & 0.65 \\
\hline $40^{\circ} \mathrm{W}$ & 63 & 1.13 & 0.62 & 65 & 1.41 & 0.72 & 65 & 0.32 & 0.20 \\
\hline
\end{tabular}

As the Table shows, sedimentation rates of TSM and SOM and TSM/SOM ratios determined for different locations of the Black Sea conform to the amount of these substances in these seawater areas and, at least partially, depend on the local hydrodynamics. In May and July intensive TSM and SOM sedimentation was registered at all stations where the set of sedimentation traps was applied, and in September at st. 23, too; the rate of sedimentation fluctuated depending on depth. According to the records gained at stations, averages of the TSM and SOM flows were evaluated ca. 1.0 and ca. $0.5 \mathrm{~g} \mathrm{~m}^{-2}$ day ${ }^{-1}$, correspondingly; increase of the sedimentation rate in July at st. 55 can be due to a local cyclonic gyre. Thermohaline disturbances were evident in the $0-200 \mathrm{~m}$ layer and only enhanced in the $0-500 \mathrm{~m}$ depth thereby evidencing considerable vertical extent of the phenomenon. At st. 96 estimates of sedimentation rate increased with depth in May, keeping high at $65 \mathrm{~m}$ depth in July; it is, probably, related to anticyclonic circulation that persisted in the area over the period of the investigation $[6$, 8].

In September, as the dynamics in the central part of the sea (st. 55) settled down to classical pattern $[4,6]$, sedimentation rates of TSM and SOM decreased to minimal throughout the sampled water column. In the eastern part of the sea the protracted anticyclonic circulation sustained sedimentation rates relatively high.

In conclusion, I would again emphasize the fact that the results we have obtained by direct measuring of SOM and TSM well agree with the relevant measurements made with the involvement of ${ }^{234} \mathrm{Th}$ in the western halistaze of the Black Sea during the same period of time [10].

\section{Conclusions}

Implementation of the unique experiment of $1992-1993$ involved the first in the history of Black Sea marine researches large-scale determination of SOM content and the related direct measurements of sedimentation rates in different seasons of the year. The investigation was carried out under specific large-scale changes in the hydrodynamic of the open-sea area of the northern Black Sea.

Compared to the 1960s, in the 1990s SOM content in photic layer of the Black Sea has increased thrice that evidences a fast increase of eutrophication and an imbalanced trophic dynamics in the ecosystem.

The seasonal fluctuations in SOM estimates which were noticed during the investigation concurred with quantitative changes in other seston components.

Direct measurements have shown that in the three inspected areas of the sea TSM and SOM sedimentation rates were relatively high due to the abundance and high quantitative variability of these substances, and also due to hydrodynamic conditions particular to the seawater localities.

The similarity of sediment carryout estimates which were nearly synchronously obtained by direct measurements and by means of thorium proves their reliability.

\section{Acknowledgements}

Materials underlying this publication were obtained thanks to the Agreement about the scientific cooperation between the IMBI (former IBSS, NAS of Ukraine) and the UkrRCME, Ministry of Environmental Protection of Ukraine (1992) in implementing the Program of researches of the annual cycle of basic ecosystem elements of the northern Black Sea during 1992-1993. The authors are grateful to V.T. Georgiev, S.A. Gerasimov and Yu.I. Popov (UkrRCME) who offered hydrological data. In the data analysis we also used results obtained from the hydrobiological investigations of micro- and mesozooplankton and some oceanographic surveys conducted during the expeditions and the studies of phytoplankton performed in March - April 1992 by V.N. Vasileva and L.A. Vinogradova (UkrRCME) who have offered these data in accordance with the scientific exchange procedure implied by the Agreement.

\section{REFERENCES}

[1] V.L. Asper. Measuring the flux and sinking speed of marine snow aggregates, Deep-Sea Res., V. 34, 1-17, 1987. 
[2] M.L. Bordenave. The sedimentation of organic matter: Applied Petroleum Geochemistry, Editions Technip, Paris, Ch. $1.2,15-76,1993$.

[3] Yu.V. Bryantseva. The variability of structural features of phytoplankton in the Black Sea: Thesis for Ph.D. (Biol.), Sevastopol: Institute of Biology of the Southern Seas, NAS Ukraine: 183 pp. (Manuscript). 2000. (In Russ.)

[4] Z.P. Burlakova, L.V. Eremeeva, S.C. Konovalov. Seasonal and spatial variability of particulate organic matter content in active layer of the Black Sea, Mar. Hydrophysical Journ., Sevastopol, 30-62, 1998. (In Russ.).

[5] Dubovskaya, O. P. Methodological principles of the using of sedimentation traps in marine and continental areas of water, Hydrobiological Journ., Moscow, V. 58. N 5, 98-110, 2002. (In Russ.)

[6] V.S. Dzitsky, N.I. Minkina, I.G. Orlova, E.Z. Samyshev. 2012. The sea water pollution survey in the northern Black Sea, Turkish Journal of Fishery and Aquatic Sciences, Vol. 12, 507-522, 2012.

[7] Z.Z. Finenko. The content of organic matter in seston of the Black Sea and the Sea of Azov: Investigation of plankton of the Black Sea and the Sea of Azov, Kiev, Naukova Dumka Publishing House, 12-16, 1965. (In Russ.)

[8] V.T. Georgiev, S.A. Gerasimov, Yu.I. Popov. Hydrodynamic conditions of open water masses in the northern half of the Black Sea: V.I. Medinets (Ed.), Investigations of ecosystem of the Black Sea, Is. 1, Ministry of Environmental Protection of Ukraine, Ukrainian Research Centre of Marine Ecology, Odessa, 17-23, 1994. (In Russ.).

[9] L.N. Gruzov, P.V. Lyumkis, G.V. Napadovsky. Researches of the spatiotemporal structure of planktonic fields in the northern Black Sea in 1992-93: Medinets (Ed.), Investigations of ecosystem of the Black Sea, Is. 1, Ministry of Environmental Protection of Ukraine, Ukrainian Research Centre of Marine Ecology, Odessa, 94-127, 1994. (In Russ.)

[10] S.B. Gulin, G.G. Polikarpov, V.N. Egorov, O.V. Krivenko, N.A. Stokozov, N.V. Gerko. Investigation of seasonal dynamics of sedimentation exportation of suspended matter, nutrients and pollutants from the surface layer of the Black Sea during 1992-1994, Geochemistry, Moscow, 863-873, 1995. (In Russ.).

[11] B.J. Hay, S. Honjo, S. Kempe. et al. Interannual variability in particle flux in the southwestern Black Sea, Deep Sea Res, Vol. 37, No 6, 911-928, 1990.

[12] S. Honjo, B.J. Hay, S.J. Manganinin et al. 1987. Seasonal cyclicity of lithogenic particle fluxes at a southern Black Sea sediment trap station, Mitt. Geol. Paleontol. Inst. Univ. Hamburg, SCOPE/UNEP Sonderband Heft, Vol. 62, 19-39, 1987.

[13] Investigations of ecosystem of the Black Sea. 1999. CSW of Ministry of Environmental Protection of Ukraine, Ukrainian Research Centre of Marine Ecology, Odessa, (Ed. V.I. Medinets), Is.1, Odessa, 158 pp., 1999. (In Russ.).

[14] Yu.P. Khrustalev, V.I. Denisov. 2002. Sedimentation rates on the shelf of the Black Sea (by the data obtained using sedimentation traps): General and regional Geology, Geology of ocean and seas, geological mapping: Overview /LLC
“Geoinformcentre", Moscow, 36 pp., 2002. (In Russ.).

[15] V.I. Medinets, L.N. Gruzov, I.G. Orlova, V.N. Vasileva, Yu.I. Popov. Investigation of annual cycle of basic elements of ecosystem of the Black Sea: (Ed. V.I. Medinets). Investigations of ecosystem of the Black Sea, Is. 1, Ministry of Environmental Protection of Ukraine, Ukrainian Research Centre of Marine Ecology, Odessa, 12-16, 1994. (In Russ.).

[16] A.F. Michaels, M.R van der Loeff., M. Sarin., D.K. Steinberg, T. Trull. An assessment of the use of sediment traps for estimating upper ocean particle fluxes, J. Mar. Res., V. 65, 345-41, 2007.

[17] Muller, P. 1979. Productivity, sedimentation rate and sedimentary organic matter in the oceans. I. Organic carbon preservation. Deep-Sea Res., A, V.26. P. 1347-1362.

[18] S.A. Murzov. The structure and seasonal dynamics of heterotrophic nanoplankton in the Black Sea: Thesis for Ph.D. (Biol.), Sevastopol, Institute of Biology of the Southern Seas, NAS Ukraine, 161 pp., 1994. (Manuscript). (In Russ.)

[19] Romankevich, E.A. The geochemistry of organic matter in the ocean. Berlin-N.Y.-Tokio: Springer-Verlag, 335 pp., 1984.

[20] E.Z. Samyshev. Suspended organic matter as index of the productivity and production-destruction processes in sea (conceptual review): Monitoring systems of environment, CSW of Marine Hydrophysical Institute, NAS of Ukraine, Is. 13, Sevastopol, 220-224, 2010. (In Russ.)

[21] V.I. Sukhoruk, E.Z. Samyshev. Quantitative relationships between organic matter components in water of the Gulf of Guinea, Gydrobiolog. Zhurnal, Vol. 5, No 3, 34-39, 1969. (In Russ.)

[22] L.M. Sushchenya. Some evidence about the amount of seston in water of the Aegean, Ionic and Adriatic seas, Okeanologiya, Vol. 1, No 4, 664-669, 1961. (In Russ.)

[23] L.M. Sushchenya, Z.Z. Finenko. Particulate organic matter content in the tropical Atlantic and some quantitative relationships between its components, Okeanologiya, Vol. 6, No 5, 835-847, 1966. (In Russ.)

[24] S.B. Tambiev, S.V. Lyutsarev, A.S. Avdonin. Composition of the freely settling matter collected with a sedimentation trap in deep-water locations of the Black Sea, Proc. Ac. Sci. USSR, Vol. 298, No 3, 724-728, 1988. (In Russ.)

[25] S.V. Vostokov. Particulate organic matter in open-sea areas of the Black Sea in spring 1984: The present state of ecosystem of the Black Sea, Moscow, Nauka Publishers, 59-67, 1987. (In Russ.)

[26] S.V. Vostokov. The dynamics of particulate organic matter during winter-and-spring phytoplankton blooms in the Black Sea: The variability of ecosystem of the Black Sea. Natural and anthropogenic factors, Moscow, Nauka Publishers, 262-271, 1991. (In Russ.)

[27] S.V. Vostokov. Suspended matter as a productivity indicator, Okeanologiya, Vol. 36, No 2, 260-267, 1996. (In Russ.)

[28] S.V. Vostokov, L.I. Korzhikova. The vertical distribution of suspended organic matter in epipelagic zone of the Black Sea (May - June 1986: The structure and production characteristics of plankton communities in the Black Sea, M, Nauka Publishers, 246-255, 1989. (In Russ.) 